Please do not remove this page

RMIT

UNIVERSITY

\title{
Beyond apologies: historical reflections on policy and practice relating to the out-of-home care of children in contemporary Australia
}

Cuthbert, Denise

https://researchrepository.rmit.edu.au/esploro/outputs/9921858426001341/filesAndLinks?institution=61RMIT_INST\&index=null

Cuthbert, D. (2010). Beyond apologies: historical reflections on policy and practice relating to the out-of-home care of children in contemporary Australia. Children Australia, 35(2), 12-17.

https://researchrepository.rmit.edu.au/discovery/fulldisplay/alma9921858426001341/61RMIT_INST:Resea rchRepository

Document Version: Accepted Manuscript

Repository homepage: https://researchrepository.rmit.edu.au

(C) 2010 Author

Downloaded On 2023/04/26 23:01:48 +1000 
Thank you for downloading this document from the RMIT Research Repository.

The RMIT Research Repository is an open access database showcasing the research outputs of RMIT University researchers.

RMIT Research Repository: http://researchbank.rmit.edu.au/

\section{Citation:}

Cuthbert, D 2010, 'Beyond apologies: historical reflections on policy and practice relating to the out-of-home care of children in contemporary Australia', Children Australia, vol. 35, no. 2, pp. 12-17.

See this record in the RMIT Research Repository at:

http://researchbank.rmit.edu.au/view/rmit:15841

Version: Accepted Manuscript

Copyright Statement: (C) 2010 Author

Link to Published Version: 


\title{
Beyond apologies: Historical reflections on policy and practice relating to the out-of- home care of children in contemporary Australia Denise Cuthbert
}

\begin{abstract}
A series of harrowing reports across the 1990s on the past removal of children, black and white, from their families have impacted on children and family policy in contemporary Australia, and on the way in which this is reported by the media and understood by the public. This paper briefly surveys some of these consequences and asks how we, as a community, can learn from the past with respect to questions of the welfare of children, without being burdened by that past.
\end{abstract}

The truth is this is an ugly story. And its ugliness must be told without fear or favour if we are to confront fully the demons of our past [ ... J. I believe we do a disservice to those who have been the victims of abuse if in any way we seek to gloss things over. Because the truth is great evil has been done. And therefore hard things must be said about how this was all possible in this country of the fair go. Unless we are now transparent about what has been done in our nation's name, our apology can never be complete. (Kevin Rudd, Apology to Forgotten Australians, November 2009)

The child is a person and not an object of concern. (Secretary of State for Social Services 1987, quoted by Smart, Wade \& Neale 1999)

All fields of public policy and professional practice are shaped by their histories. However, there are few areas of policy and practice whose histories have been so publicised, politicised and brought to bear so heavily on the story of the nation as that of child protection, child welfare and the out-of-home care of children in Australia. To date, there have been national apologies delivered by the Prime Minister Kevin Rudd in February 2008 to the indigenous Stolen Generations; to children removed from their families and placed in institutions, and to imperial child migrants in November 2009 (Rudd 2008, 2009); and, there are currently underway consultations regarding a comparable apology to mothers and children separated at birth through past adoption practices in Australian states and territories regarding which there have been two extensive teleconferences with key stakeholders in November 2009 and April 2010 and the commissioning by the Federal Government of a review of research literature on 
the impact of past adoption practices on parties to the adoption (Higgins 2010). In light of this recent history, it might be argued that Australia's past policy and practice with respect to children, specifically the removal of children from their families, are now the focus of a major project of national reconciliation.

This has significant implications for the ways in which the fields of child protection, child welfare and the out-of-home care of Australian children are viewed by the Australian public and how they are handled by the media. Both have consequences for policy in this area and for those professionals working with children and their families. This brief essay draws on research undertaken as part of the Australian Research Council funded History of Adoption in Australia (Monash University 2009). To reflect on this history, consider some of its implications and ask how we as a community, including those of us who work in these fields, can corne to terms with this history, learn the necessary lessons from it, and move beyond it to begin to frame better policy and services for vulnerable families and for the out-of-home care of Australian children.

\section{Facing up to 'Ugly’ Histories of the Treatment of Children in Australia}

Over the course of more than a decade, a series of major public inquiries has exposed to public scrutiny aspects of the history of the treatment of children - particularly the removal of children from their families - in Australia. These inquiries are the Human Rights and Equal Opportunity Commission's inquiry into the stolen generations which reported in 1997 in Bringing them home: Report of the National Inquiry into the separation of Aboriginal and Torres Strait Islander children from their families (HREOC 1997); the Australian Senate Community Affairs References Committee’s inquiry into child migration schemes to Australia and the fates of the children involved which reported in 1999 in The Lost Innocents (Parliament of Australia 1999) and, the Australian Senate Community Affairs References Committee's inquiry into Australians who were removed from their families as children and placed in institutional care, which reported in two parts - part one in 2004, The Forgotten Australians, followed in 2005 by Protecting vulnerable children: A national challenge (Parliament of Australia 2004, 2005).

In addition to these national inquiries, further state-based inquiries during this same period investigated and reported on the impact of past adoption practices. While it is beyond the 
scope of this essay to explore the relationship in more detail, it may be noted that agitation in Indigenous communities and from Indigenous service organisations which ultimately gave rise to the HREOC national inquiry into indigenous child removal shares many parallels with the movement which developed in the mid to late-1 970s for adoption reform, and which ultimately gave rise to inquiries in the states of New South Wales and Tasmania. For those fighting for reform of adoption legislation and practice in Australian states and territories, many of the issues were similar to those facing Indigenous activists and organisations on the question of Indigenous child removal: the on-going sense of loss, including the loss of identity, felt by individuals removed from mothers and adopted, and the ongoing pain and suffering of the mothers and families whose children were taken. In the wake of adoption reforms, which commenced in Victoria in the early 1980s, mothers finally reunited with their children mobilised politically and secured major parliamentary inquiries in two Australian states. A Tasmanian Parliamentary inquiry reported in 1999 (Parliament of Tasmania 1999); while a Parliament of New South Wales inquiry tabled its final report in 2000 (Parliament of New South Wales 2000). As with the Commonwealth Parliamentary and other inquiries listed above, these inquiries delved into the largely hidden history of yet another chapter of Australia's history of the treatment of children and reported on the long-term impact on parties to adoption, particularly mothers and children separated at or shortly after birth, of past adoption practices. And, as with the Commonwealth inquiries, both of these inquiries in their final reports contributed significantly to the shifting of public discourses on policy in this area by foregrounding the voices of the women and their children directly impacted by past policy.

Each of the five inquiries outlined here deals with a separate and distinct history of the removal of children from their parents, families and communities and these important differences and distinctions need always to be borne in mind. Nonetheless, there are striking commonalities of experience across these distinct histories as even a cursory reading of the transcripts of evidence given, written submissions, and the final reports makes quite clear. Reading across the reports of these inquiries, the highly individual narratives read as a continuous text of pain, powerlessness, and the lasting legacy of disruption and loss. Each of these histories involves the more or less systematic removal of certain groups of children from families, wholly justified as being in the best interests of those children by the prevailing philosophy and policies of the time. Notwithstanding what might be seen to be the best intentions of those responsible, the removals have in many cases produced as much or 
greater harm than that which they sought to prevent, inflicting long-term harm on many of the children and families from whom they were removed. The removals involved the exercise of authority by those in power - governments, churches, the professions - to determine who was fit to raise children and who was not. Many Indigenous families were considered unfit, as were many single women, and others were disqualified on the basis of little more than 'hard time ... illness, poverty and death’ (Rudd 2009).

While recognising the distinctiveness of the experiences of the various groups concerned, it is important also to recognise the compound effect of the public revelations of the hardships and on-going suffering inflicted by past policies and practices involving children. The revelations contained in these grim reports came in quick succession in the years between 1997 and 2005 with a lasting impact on the public imagination; for many Australians, the revelations in these reports profoundly challenged their sense of what it is to be Australian. As the Prime Minister expresses it in his 2009 apology to the Forgotten Australians and former child migrants, 'hard things must be said about how this was all possible in this country of the fair go' (Rudd 2009). The Stolen Generations followed by the Lost Innocents and the Forgotten Australians entered the Australian lexicon and continue to haunt the public imagination, challenging our sense of ourselves as a nation and the values which Australian nationhood supposedly represents.

Further, these inquiries and the 'hidden' history they reveal have had direct impact on policy makers. For example, in the Parliament of New South Wales, a second reading debate on the Adoption Bill (2000) took up the issue of permanency planning for children in foster care and the considerable tensions between the children's need for permanency and their connections to their birth families. The spectre of the Stolen Generations and the imperative on legislators to learn the lessons of history hover over this debate, as evinced in the following words of the Hon. J. P. Hannaford:

The only occasion on which we departed from the principle of the primacy of parents as parents, and the primacy of the role of parents to voluntarily relinquish parental control, was when we dealt with Aborigines in that way. We are now coming to grips in this country with the issue of the stolen generation. If we adopt the policy direction that the permanency planning bill takes, we will create a white stolen generation. We should learn from history in that regard [ ... J We should be trying to find ways to address the needs of those children and their support network, no matter what that 
may involve, rather than saying that we as the State will make a determination that parents will no longer have legal care and custody of their children. That is just bad policy. (Parliament of New South Wales Hansard 2000)

Coming to terms with these harrowing and 'ugly' (Rudd 2009) histories has become a distinctly Australian project of national reconciliation. Significantly, in other nations, coming to terms with past injustices within the framework of reconciliation has commonly (but not exclusively) involved atonement for atrocities committed in times of war or civil turmoil (Noble 2008). In Australia, the national project of reconciling with a shameful past has centred on the treatment of children and the role of government, whether through omission or commission, in inflicting suffering on children or failing to protect them from suffering and abuse. Beginning with the long-awaited apology to the indigenous Stolen Generations, delivered by the Prime Minister Kevin Rudd in February 2008, this process of national reconciliation and healing then turned to the Forgotten Australians and imperial child migrants who received their apology in November 2009, and now looks set also to extend to mothers and children separated by past adoption policies and practices.

As indicated above, the Commonwealth government has now embarked on a consultation process with affected groups and individuals on the question of a comparable apology to the women, mostly single mothers, who lost children to forced or coercive adoption practices in the decades following World War II. The case of those affected by past adoption practices differs somewhat from that of other groups who have received apologies in several respects. Most particularly, this history has not been the subject of a Commonwealth Parliamentary or national inquiry as in the cases of Indigenous removed children, children placed in institutions and the imperial child migrants. In the absence of a national inquiry, the present process of consultation is designed to provide the evidentiary base which will inform Commonwealth on the appropriateness of an apology to parties to adoption (Higgins 2010).

In the following sections of this paper, I briefly canvass some of the major consequences for contemporary policy and practice of these inquiries into past practice.

\section{'Objects' Being Heard as 'Subjects': Placing the Voices of Those Affected by Past Policy on the Historical Record}


A significant consequence for the formulation of policy and the delivery of service of this series of high level inquiries into past policy and practice in the out-of-home care of Australian children has been the prominent emergence of former 'objects' of policy ostensibly concerned with their welfare as speaking 'subjects' placing their stories and experiences on the historical record. The transformation of objects of policy into visible, audible, historical subjects represents a profound (and hopefully productive) challenge to the way in which policy is formulated and services delivered.

The methodology of these inquiries, most significantly that of the HREOC (1997) inquiry into the removal of Indigenous children from their families and communities, centred on the testimonies and submissions of men and women who were removed as children. As well as reviewing historical documents and hearing from 'experts', each of the inquiries detailed above devoted considerable time and resources to the receipt and processing of written submissions from people directly affected by past policy and practice and to the convening of public fora and community consultations in which individuals could speak directly with the commissioners and committee members. As such, the process of inquiring into past practices brought the voices of those who were the 'objects' of past policies and practice into the public domain.

The emergence in the public domain of these 'objects of concern' (Smart, Wade \& Neale 1999) as adult speaking subjects profoundly challenged conceptions of where 'expertise' in the matter of the welfare of children actually lies, and served as indisputable evidence that policy framed for children's welfare needs to be cognisant of the interests both of the present child and the future adult. In each of the five inquiries outlined here, hundreds of Indigenous and non-Indigenous men and women removed from their families as children for 'their own good' spoke eloquently and passionately of the lived reality of their lives under welfare regimes which failed to protect them and, in many cases, inflicted greater harm than that which they were intended to prevent.

For practitioners working with children and their families, working through the implications of this historical legacy is a matter of constant soul-searching and reflective professional practice. The statement made by the Australian Association of Social Workers in 1997 on the role of social workers in past adoption practice recognises a decentring of the professional as expert in this field: 
The Australian Association of Social Workers Ltd (AASW) expresses its extreme regret at the lifelong pain experienced by many women who have relinquished their children for adoption.

In doing this, we recognise that decisions taken in the past, although based on the best knowledge of the time, and made with the best intentions, may nevertheless have been flawed (Statement about Adoption by the Australian Association of Social Workers, 12 June 1997, quoted in Parliament of Tasmania 1999, p.10).

As expressed succinctly by George Habib during discussion on this topic on the first day of the Adoption, Fostering, Permanent Care and Beyond symposium, this critical reflection on practice starts and ends with the following consideration: are we making the best decision for this child now, and will it remain the best decision to have made in twenty years' time?

\section{Highlighting the Tensions Between the Framing of Children's Policy Within a 'Welfare' Paradigm and a 'Rights' Paradigm}

The inquiries into past practice in the welfare of children further highlight the significant tensions between children's immediate and often pressing need for safety and security and perhaps less pressing but significant considerations of their need for ongoing contact with and knowledge of their birth family, extended family and community. These tensions are usefully framed and discussed by British social work academic Penelope Welbourne as those between children's needs conceived primarily within a welfare framework as distinct from their framing within a rights framework (Welbourne 2(02). While focussed specifically on the tensions between welfare considerations (the need for safety, security and stability) and rights considerations (the need for ongoing contact with birth family, as enshrined in international rights charters) in the context of adoption in the UK, Welbourne' s work is rich in significance for considering children's policy more broadly. In particular, it is relevant to the situation in Australia in which policy makers and service providers attempt to deal with the present needs of vulnerable or at risk children under the shadow of the history of the harm inflicted by past policy and practice in this area. Balancing the present welfare needs of children with their present and ongoing rights with respect to contact with and knowledge of family and culture remains a significant challenge for which there are no easy solutions. Scrupulous professional practice is required to negotiate the competing interests, and bring 
about the best outcomes (or, at least, minimise the harm done) to children. We need to avoid a situation, as existed in the past, where understandings of the child's present welfare needs prevailed to the exclusion of other considerations, such as their present and ongoing needs for connectedness to family and community. As we in Australia know only too well, 'welfare' policy wielded in this manner is a blunt and dangerous instrument which can inflict harm as great or greater than that which it seeks to prevent. At the same time, we need also to be wary of going too far in the other direction, as Welbourne argues:

It would be unfortunate ... [if] children grew up to tell of the damage they feel they have experienced as a result of the maintenance of links they found difficult and disruptive but hard to resist (Welbourne 2002, p. 287).

For Welbourne, the way forward is reflective practice, further research and a commitment on the part of all concerned in the legal and administrative/welfare system to the paramountcy of the rights and interests of the child (which encompass the rights and interests of that child as an adult in the future) 'over other, adult interests' (Welbourne 2002, p. 287).

\section{CONCLUSION}

The challenges faced by those working in children's services, and for the community as whole, were further graphically highlighted in the course of the two-day symposium in Melbourne with the tabling of the Ombudsman's report into child protection in Victoria (Ombudsman of Victoria 2(09). Children's services are, it seems, constantly caught in the cleft stick of growing community needs, strained resources, and critical media and public opinion, with the latter habitually resorting to unproductive, old stereotypes of 'unfit' families and 'bad' parents to account for the situation of many vulnerable children in Australia.

Damned by a history of frequently well-intentioned but also frequently misguided intervention into the lives of vulnerable children and their families, contemporary children's services often seem equally damned in the present by assessments of their failures to intervene (Devine 2006).

Moving beyond this history requires from the profession and the community at large a practical awareness that each child 'is a person and not an object of concern' (Secretary of State for Social Services 1987); and this applies irrespective of how 'concerning' the predicaments of many children in need of care might be. As such, children have capacities to express their views and assess their needs; and space must be made for this to occur and to be 
communicated. George Habib’s injunction, referred to above, that we consider the appropriateness of all actions - not only in present circumstances but, as far as possible, into the future - is surely an indispensable constituent of respectful and reflective professional practice. Making space for children and their families to speak and making time in our policy development and practice actively to listen to them must never again be something that only occurs 20, 30 or even 50 years post-fact in commissions and special parliamentary inquiries. Hearing (and truly listening to) the voices of children and their families must occur at every stage of the development of policy and the delivery of services, and these must be then subject to on-going review.

The engaged deliberations which took place in Melbourne in November 2009 involving around 90 professionals with direct involvement in the out-of-home care of children is just one of many indications of the commitment to work with children and families in need which has transformed, and continues to transform, practice in this field. However, as crucial as the respectful and reflective professional practice of social workers and other professionals is to the achievement of better outcomes for children, this is not something that can be achieved by these professionals alone. Services for children and their families across the spectrum need to be better funded and supported by government. Education and ongoing professional development and support for all professionals in the field are also vital. Universities need to rise to the challenge of providing better targeted undergraduate and postgraduate curriculum in fields such as child protection and the out-of-home care of children; and, because this history is still with us, this curriculum should also contain critical modules on past practice and its outcomes to better support the critically-reflective and historically-aware policy and practice neededin this field. And, research is also needed: what works for children in out-ofhome care, what doesn't, and how do we know? This points to a further area in which universities, government and community service organisations need to form partnerships and collaborations. The media, too, must play a role - it must move beyond knee-jerk reporting which reproduces old stereotypes and fails to provide systematic analysis by resorting to scapegoating and the targeting of whipping boys to account for deficiencies in the system. The media can also contribute to mature and responsible community debates on these issues. Academics and researchers, too, must play a further role in both assisting with greater understanding of past practice, and evaluations of present policy. 
Finally, actively moving beyond our grim national history in this area is a responsibility of the entire community. All of us must work in our various capacities to ensure that children and the services they require are given political priority within a policy and practice framework focused on the needs and interests of the children themselves. For, as has been made clear in the two national apologies on past practice in the treatment of children, blame for such immense failures can rarely be laid at the feet of individuals or groups but must be owned by the community at large. What has been done in the name of the nation becomes a national shame (Rudd 2009). Where the national community has acknowledged its shame for the past, it must also assume responsibility for the future. •

\section{REFERENCES}

Devine, M. (2006) 'Suffering of Un-stolen generation deserves public outcry and apology,' Sydney Morning Herald, 23 July.

Higgins, D. (2010) Impact of past adoption practices: Summary of key issues from Australian research. Final Repon. A repon to the Australian Government Depanment of Families, Housing Community Services and Indigenous Affairs, Canberra.

Human Rights and Equal Opportunity Commission (HREOC) (1997) Bringing them home: Repon of the National Inquiry into the Separation of Aboriginal and Torres Strait Islander children from their families, Canberra.

Monash University (2009) The search for family: A social and political history of adoption in Australia, website $<$ http;IIarts.monash.edu.aulhistoryofadoption/>.

Nobles, M. (2008) The politics of official apologies, Cambridge University Press, New York. Children Australia Volume 35 Number 2, 2010.

Ombudsman of Victoria (2009) Own motion investigation into the Department of Human Services Child Protection Program, November 2009, Melbourne: Government Printer. Also available at:

$<$ http://www.ombudsman.vic.gov.auiresourcesJdocumentslInvestigation_into_the_De partmencoCHuman_Services_Child_Protection_Program.pdf>.

Parliament of Australia, Senate Community Affairs References Committee (1999) Lost Innocents: Righting the record - Report on child migration, Commonwealth of Australia, Canberra. 
Parliament of Australia, Senate Community Affairs References Committee (2004) Forgotten Australians: A report on Australians who experienced institutional or out-of-home care as children, Commonwealth of Australia, Canberra.

Parliament of Australia, Senate Community Affairs References Committee (2005) Protecting vulnerable children: A national challenge, Commonwealth of Australia, Canberra.

Parliament of New South Wales, Legislative Council Standing Committee on Social Issues (2000) Releasing the past: Adoption practices 1950-1998, Sydney.

Parliament of New South Wales Hansard (2000) Legislative Council, 6 September 2000, accessed on 6 February 2010 at:

$<$ http://www.parliament.nsw.gov.auiprodlPARLMENTlhansArt.nsfN3KeyILC20000 906030>.

Parliament of Tasmania, Joint Select Committee (1999) Adoption and related services 19501988, Hobart.

Rudd, Kevin. (2008) ‘Apology to Australia’s Indigenous Peoples’, House of Representatives, Parliament House, Canberra, 13 February 2008, accessed on 31 January 2010 at: $<$ http://www.pm.gov.auinodel5952>.

Rudd, Kevin (2009) 'Address at the apology to the Forgotten Australians and former child migrants, Great Hall, Parliament House’, 16 November 2009, accessed on 31 January 2010 at <http://www.pm.gov.auinode/6321>.

Secretary of State for Social Services (UK) (1987) Report of the Inquiry into Child Abuse in Cleveland, London.

Smart, C., Wade, A. \& Neale, B. (1999) 'Objects of concern? Children and divorce,' Children and Family Low Quarterly, 11,4, 365-76.

Welbourne, P. (2002) 'Adoption and the rights of children in the UK', International Journal of Children's Rights, 10,269-89.

Denise Cuthbert is currently Head of the School of Political and Social Inquiry at Monash University. She has published widely on a range of topics with a focus on gender, children and families, including a number of articles on adoption and fostering. She is currently working with Marian Quart/y, Shurlee Swain, Nell Musgrove and Amy Pollard on an Australian Research Council funded history of adoption in Australia. 